\title{
CONSTRUCTION CONTRACT OF HIRE PURCHASE AND CORRELATION WITH CRIMINAL OFFENSE
}

\author{
Bambang Tri Bawono \\ Faculty of Law Unissula \\ bambang@unissula.ac.id
}

\begin{abstract}
Hire purchase agreements that have developed in the realm of society yet have clarity because there is no specific legislation governing the lease-sale agreement. The absence of specific legislation governing the lease resulted in the agreement to experience different views for legal experts both in terms of the definition and the legal consequences arising. This type of research used in this study is a research library with normative juridical approach. Normative research. The results of this study mention: first, the legal construction of a hire purchase agreement did not have legal certainty, because this agreement has legal consequences of changing from the payment of the debt to the payment of rent, when a tort committed by the purchaser. Other than that, construction law hire purchase agreement is null and void, because there are some clauses which are contrary to Article 1266 of the Civil Code and Article 18 of the Consumer Protection Act. Second, the criminal offenses arising from a lease agreement is a criminal offense of extortion, when the withdrawal unilaterally, although financing the vehicle has been registered in the Register of Fiduciary. This is because even though the fiduciary has the right of executor, but the execution must follow procedures for the implementation of a court decision, so businesses must apply in advance to the Chairman of the Court.
\end{abstract}

Keywords : Construction Law, Criminal offense, Hire Purchase Agreement.

\section{A. INTRODUCTION}

The development of the economic system in the era of globalization provide enormous influence on the model of economic transactions carried out in various countries. Including Indonesia, the development of the economic system also influence the emergence of new types of transactions that are not known in Bugerlijk Woetbok (BW). This day, unknown transactions such as lease agreements, lease (leasing), factoring (factoring), and other transactions in the same breath with such transactions. In this case, the lease agreement and purchase a new agreement that developed as a result of customs and business needs in the realm of society. ${ }^{1}$ Term lease-sale agreement basically just has been known after the Decree of the Minister of Trade and Cooperatives Number 34 / KP / II / 1980 February $1^{\text {st }}$, 1980 on Licensing of Leasing Operations (Hire Purchase), Purchase by installment, and Rent (Renteng). However, to encourage the creation of a conducive business climate and efficient,

1 Vienna P. Setiabuddi, Default Vehicle Hire Purchase Agreement, Unsrat Law Journal, Vol. 1, Number 1, 2013, p. 95. 
then some licensing and registration provisions stipulated in the Decree of the Minister of Trade and Cooperatives Number 34 / KP / II / 1980 on Licensing of Leasing Operations (Hire Purchase), Purchase by installment, and Rent is deleted. It is based on the Regulation of the Minister of Trade of the Republic of Indonesia Number: 21 / M-DAG / PER / 10/2005 concerning Licensing and Registration Revocation Some in the trade sector. ${ }^{2}$

The revocation of the Decree of the Minister of Trade and Cooperatives in the end result until now there is no specific legislation governing the lease-sale agreement. The absence of specific legislation governing the lease-sale agreement resulted in this agreement is born with based on the principle of freedom of contract as provided in Article 1338 paragraph (1) of the Civil Code. Article 1338 paragraph (1) of the Civil Code describes each individual may perform any agreement, anytime, and anywhere along fulfill the terms of the agreement valid and does not conflict with applicable law in Indonesia. ${ }^{3}$

Hire purchase agreement that has been widely used by businesses and real buyers do not yet have clarity, because the lease purchase transactions is still causing disagreement among legal experts are well reviewed by definition and the legal consequences thereof. In this case, there are at least three views on the definition of a lease. The first definition of the view that the same lease with purchase installments. While the definition of a lease both found the same as the lease. While the third definition states that a lease is a lease of mixing between the act and the act of buying and selling. ${ }^{4}$

In the Civil Code, the rental agreement under Article 1548 of the Civil Code which states that "a lease is an agreement whereby one party to bind himself to give the other party the enjoyment of the goods during a specified period and the payment of something the price by a third the latter was affordable payment. ${ }^{5}$ While the purchase agreement under Article 1457 of the Civil Code which states that "the sale and purchase is an agreement whereby one party to bind himself to submit a material and the other party to pay the agreed price." 6 The existence of the legal confusion became clear, when looking at the legal consequences arising from a lease deed and act of buying and selling. The legal consequences arising from the deed of transfer of the lease is the mastery of a specific period without being accompanied by the transfer of ownership, while the legal consequences arising from the act of purchase is the acquisition and transfer of ownership from one party to another party.

The other side of such legal uncertainty, hire purchase agreements that occurs in general also use raw deal, so that the contents of the agreement from the beginning has been made by businesses without involving the buyer. The lack of involvement of the buyers in making the agreement ultimately resulted in this agreement is likely to strengthen the

2 Jeinal Bawarodi, Hire Purchase Agreements Implementation in Indonesia and Effect Law, Lex Privatum, Vol. II, Number 3, 2014, p. 11.

3 Suharnoko, Contract Law Theory and Legal Analysis, Cet. Ninth, Kencana, Jakarta, 2015, p. 65.

4 Salim HS, innominate Contract Law Developments in Indonesia, Cet. Fourth, Sinar Grafika, 2008, p. 128.

5 Libertus Jaehani, A Practical Guide to Make Agreements and Their Examples, Cet. Second, Visimedia, South Jakarta, 2007, p. 23.

6 Munir Fuady, Business Law in Theory and Practice Book Three, Cet. Third, Pt. Citra Aditya Bakti, Bandung, 2017, p. 256. 
rights of the seller of a variety worst possible during the contract period. In general, the clauses contained in the lease-sale agreement includes about procedures for the installment, the rights and obligations of the parties, and the right of businesses to attract the object of a lease if the buyer does not perform its obligation to make installment payments for several months in a row?

Based on some of the clauses set forth in the lease agreement to buy the above, because of the law of treaties set out in the Civil Code adopts a default when there is a discrepancy between the implementation of the agreements that have been agreed upon, then the lease-sale agreement also has the same consequences, when there is a discrepancy between execution and an agreed arrangement. Hire purchase agreement contains standard clauses for the sake of strengthening the rights of the seller of a variety worst possible actually only lead to imbalance, so this is contrary to the purpose arbitrate which seeks to establish a balance and fairness to all parties. ${ }^{8}$

Apart from such legal uncertainty, hire purchase agreements were born and developed based on the principle of freedom of contract must fulfill the terms of a valid agreement as set forth in Article 1320 of the Civil Code. Article 1320 of the Civil Code explains that "For the validity of approvals required four conditions, namely those who bind themselves agree; ability to bind themselves; a certain thing; and a cause that is kosher." ${ }^{9}$ The first requirement and the second is referred to as the subjective condition because it involves the parties make an agreement. While the third and fourth terms is referred to as an objective requirement, as it relates to the object of the agreement. ${ }^{10}$ Referring to the terms of the agreement, the four conditions consisting of subjective and objective requirements are an essential part of the legitimate or not an engagement. Furthermore, the four conditions that are categorized as a condition for the subjective and objective conditions also have different consequences when one of them is not match. Consequences of non-fulfillment of subjective terms (and prowess agreement parties) are able to be requested cancellation (canceling) to the court. While the consequences arising from objective conditions (because of certain things and kosher) are therefore null and void (null and void). ${ }^{11}$ The impact of an agreement which is null and void is considered an agreement never happened, so the parties must restore everything that has been agreed as usual. ${ }^{12}$

Based on the description of the background of the problem, then the problem in the study as follows:

1. How the legal construction of a hire purchase agreement?

2. How criminal offense arising from the rental agreement to buy?

7 Vienna P. Setiabuddi, Default Vehicle Hire Purchase Agreement, op.cit, p. 97.

8 Ibid, p. 98.

9 Salim HS, Contract Law Theory \& Mechanical Drafting Contracts, Cet. 11, Sinar Grafika, Jakarta, 2015, p. 33.

10 I Ketut Oka Setiawan, Legal Engagement, Sinar Grafika, Jakarta, 2016, p. 61.

11 Ibid, p. 74.

12 Kartini Muljadi and Gunawan Widjaja, Engagement Born of the Agreement, Cet. Sixth, PT. King Grafindo Persada, Jakarta, 2014, p. 182. 


\section{B. Research methods}

The approach used in this study is normative or often referred to as a normative legal research. Soerjono Soekanto define normative research is a series of legal research done by researching library materials or secondary data as the base material to be tested by conducting a search of the regulations and literature relating to the cases studied. ${ }^{13}$

Specifications research used in this research is descriptive analytical because it seeks to describe and analyze problems based on certain specifications. ${ }^{14}$

\section{Results and Discussion}

\section{Construction Law Hire Purchase Agreements}

Lease was originally a practice arising from the question of the desire to buy goods, but the prospective buyers could not pay in cash. Starting from that issue, the seller then willing to accept payment by installments or in installments, but the sellers also need assurances that the goods will not be sold by the purchaser before it is paid off. As a way out that is present to bridge the problematics so, then comes the hire purchase agreement as efforts to transfer control of the goods to the buyer with a system of leasing and transfer of ownership will take place after the repayment installments. ${ }^{15}$

Hire purchase agreement that was originally used as a way out to resolve the above problems would lead to ongoing problems, because the lease purchase transactions not yet have clear provisions, thus still causing differences for the jurists, both in terms of the definition and the legal consequences arising. In this case, there are at least three definitions of hire purchase agreements. The first definition of the view that the same lease with purchase installments. Definition of the first of these contained in Articles $1576 \mathrm{H}$ Book IV of NBW saying that "huurkop or hire purchase is selling installment (of atbelating) where the parties agree, the goods sold are not directly belong to the buyer with the delivery of the goods." While the second definition found the same lease with a lease. ${ }^{16}$ While the third definition states that a lease is a lease of mixing between the act and the act of buying and selling. This third definition proposed by Soebekti who said that the lease agreement is the actual buying and selling practices, at least this agreement is closer to the act of buying and selling compared with meyewa lease deed, lease deed although a mixture of both. In harmony with these opinions, Salim HS also mentioned that a lease is a combination of two kinds of legal construction, namely construction law and construction law lease purchase. ${ }^{17}$

13 Soerjono Soekanto and Sri Mamudji, Normative Legal Research (A Brief Overview), Eagle Press, Jakarta, 2001, p. 13.

14 Suteki and Galang Taufani, Legal Research Methodology (Philosophy Theory and Practice), Eagle Press, Jakarta, 2018, p. 133.

15 R. Subekti, Assorted Testament, Pt. Citra Aditya Bakti, Cet. All 10, Bandung, 1995, p. 52.

16 Sandrina Wijaya, Deal Direct Mail Business Agreement, op.cit, p. 18.

17 Salim HS, innominate Contract Law Developments in Indonesia, op.cit, p. 129. 
In connection with this fact, the absence of regulations governing hire purchase agreement also led to this agreement was born and developed the basis of the principle of freedom of contract. With reference to the principle of freedom of contract, each person is allowed to hold any agreement, although not regulated in the legislation is not contrary to morality, public order and law. ${ }^{18}$ In addition, this agreement also must meet all of the terms of a valid agreement as set forth in Article 1320 of the Civil Code. Article 1320 of the Civil Code explains that "For the validity of approvals required four conditions, namely those who bind themselves agree; ability to bind themselves; a certain thing; and a cause that is kosher. ${ }^{19}$ "

First, Agreed they were tied up. Terms of the deal gives the sense that the parties expressed mutual desire of each to seal an agreement or statement of the first match or correspond with the other party. The agreement is a declaration of will that consists of two elements, namely offer and acceptance. Elements offers will be interpreted as a statement containing proposals for an agreement. While the reception is the agreement of the other parties were offered. ${ }^{20}$ Elements offers contained in the lease-sale agreement made by businesses using a standard clause, so that the buyer can only approve or reject it. While the agreement made in this agreement is also not expressed in writing with the agreement at the end of the agreement. However, the signatures affixed in the end of the agreement at least show that there is action to the approval given by the buyer. It is grounded in the view of Adrian Mc Cullagi, Peter Little, and Wiliam Caeli saying that the signature function is to identify a signatory, provides certainty of one's involvement, stating one's intention to be bound by the contents of the document, stating the ownership of the document was the signatory, ${ }^{21}$ In addition Agus Yudho Hernoko also stated that the statement will not always explicitly stated, but it can be shown by the behavior or statements will of the parties. $^{22}$

Second, Ability to bind themselves. Skills are defined in terms of agreement is the ability to conduct legal action. Ability to conduct legal action is generally measured in Person (private) through the standard age of maturity and Rechperson (entity) through aspects authority. Ability to conduct legal action for the person generally measured through a standard age of majority or age (beekwamheid-meederjarig). Only, in the case of a standard measurement of adult age was also cause differences, some have argued that given the standard age of maturity is 21 years on the basis of Article $1330 \mathrm{BW}$ jo. $330 \mathrm{BW}$. While there is also the opinion that the standard age of maturity is 18 years, based on Article 47 jo. 50 of Law Number 1 of 1974 on Marriage. ${ }^{23}$ Accordingly, Article 1 of Law Number 35 of 2014 on the Protection of the

18 Marilang, Legal Engagement, Engagement Born of the Agreement, Indonesia Prime, Makasar, 2017, p. 148.

19 Salim HS, Contract Law Theory \& Mechanical Drafting Contracts, op.cit, p. 33.

20 Agus Yudho Hernoko, Contract Law; The principle of proportionality in Commercial Contracts, op.cit, p. 162.

21 HR Daeng Naja, Contract Drafting; Skills Series Designing Business Contracts, Citra Aditya Bakti, Bandung, 2006, p. 347.

22 Agus Yudho Hernoko, Contract Law; The principle of proportionality in Commercial Contracts, op.cit, p. 162.

23 Samuel Mp. Hutabarat, Offer and Acceptance in the Contract Law, Grasindo, Jakarta, p. 70 
Child which states that "the child is a person under 18 (eighteen) years, including children who are still in the womb." In addition, another provision which states that the standard of maturity when a person 18 years of age is also emphasized in Law Number 3 of 1997 on Juvenile Justice (Vide Article 5 Jo.61), Law Number 30 of 2004 on the Rules of Notary (Vide Article 39 jo. 30), and Number 12 of 2006 on Citizenship of the Republic of Indonesia (Vide Article 5, jis, 6, 9, 21, 22, and 41). Furthermore, even the Dutch are used as a reference source of law concerning the standard of maturity, which initially stated that the standard age of adulthood is 21 years old, ${ }^{24}$ Referring to the terms of the skills that have been described thus, the lease purchase credit motor in accordance with the terms of skills, given the credit application motor vehicle with a lease-sale agreement generally have terms as follows: an Indonesian citizen (citizen), aged at least 21 years, copy of ID card (for those who have a spouse must include also a copy of ID pairs), copy of KK and a marriage certificate (for married), copy of salary slips, to request a credit of 50 million or more must include the TIN, and at some dealers also asked for the bill electricity or water.

Third, A particular case. The purpose of a particular case or a particular object is an accomplishment that the subject of the contract in question. Achievements of the agreement should be clear, because of the requirement relating to a specific case the rights and obligations of both parties. ${ }^{25}$ Explanations about a particular thing in substance can be referenced by Article 1331, 1332, and Article 1333 of the Civil Code. Article 1331 paragraph (1) explains that "an agreement must have the subject of an object can be determined that at least its kind." Meanwhile, Article 1332 of the Civil Code also states that "only a tradable item that can be the subject of agreement". While Article 1333 of the Civil Code also states that "A treaty shall have the principal form of an item is at least the specified type. The amount of goods that do not need to be sure, so long as the amount can be calculated or determined. "The substance of those chapters provide guidelines that the contract should be known clearly about the object that formed the basis for an appointment. ${ }^{26}$,

Fourth, the cause is kosher. Teachings about the terms causa or cause kosher basically adopting the French Civil Code sourced from view Domat and Pothier. The notion of causa lawful cause or closely related to Article 1335 and 1337 of the Civil Code. Article 1335 of the Civil Code explains that "an agreement made without cause or be made to cause false or illicit do not have the strength." Meanwhile, Article 1337 of the Civil Code explains that "a cause is prohibited to the extent prohibited by law, or if contrary to decency or order general". ${ }^{27}$ Based on the explanation, the conditions in the agreement because kosher necessarily relates to the content of the agreement should not be contrary to law, morals and public order.

24 Oemar Mochtar, Fundamentals of Engineering Manufacture Deed, Airlangga University, Surabaya, 2017, p. 52.

25 Dora Kusumatsusi, Banking Credit Agreement in Perspective, Deepublish, Yogyakarta, 2019, p. 16.

26 Agus Yudho Hernoko, Contract Law; The principle of proportionality in Commercial Contracts, op.cit, p. 191.

27 Ibid, p. 196. 
The other side of it, in the lease-sale agreement in general also has a clause that states "The state of neglect or default resulted lease-sale agreement is canceled by itself without the necessary decision of the court which means that both sides have agreed to release all the provisions that have been included Article 1266 of the Civil Code ". The existence of this clause gives the sense that in a state of neglect or default, the cancellation of the agreement is not necessary the decision of the court, so that both parties have approved the cancellation of the agreement by removing the provisions set forth in Article 1266 of the Civil Code. Further, the inclusion of a clause that seeks to cancel its own without a court ruling is certainly contrary to the provisions contained in Article 1266 of the Civil Code, for Article 1266 states that: "Terms canceled deemed always be included in the agreements are reciprocal, when one party does not fulfill obligations. In such cases, consent is not void, but the cancellation must be requested to the judge. This request should also be conducted despite terms of the non-fulfillment of obligations canceled stated in the agreement. If the condition is not stated in the agreement void, the judge is free to the state according to the request of the defendant, to provide a period of time to still meet its obligations, ${ }^{28}$ The existence of some standard clauses that are contrary to law as described above indicate that the lease agreement does not fulfill the objective conditions such as causa or cause kosher, resulting in this agreement is null and void. ${ }^{29}$ Consequences of the agreement which is null and void is considered an agreement never happened and return to its original state, so that the buyer must return the object of leasing to businesses, while businesses also have to return the money to the buyer installments. ${ }^{30}$

\section{Criminal offenses The Incurred From Hire Purchase Agreements}

The word comes from the Latin offense dellictum. In Dutch criminal law, the offense known as straafbar feit which means crime. Hazewinkel Suringa defines straafbar feit as a human behavior at a given moment has been rejected in a social life and be regarded as conduct that should be eliminated by the criminal law by using the means of coercive contained therein. Similarly, the Pompe also defines strafbaar feit as a violation of norms (disruption of legal order) who intentionally or unintentionally been done by an actor, where sentencing of the offender is necessary for the maintenance of the rule of law and ensuring the legal interest. ${ }^{31}$

Based on both these definitions, then the crime is prohibited by a rule of law, that prohibition is also accompanied by a threat (sanctions) for certain criminal

28 R. and R. Tjirosudibio Subekti, the draft Civil Code, Burgelijk Wetboek with the Additional Basic Agrarian Law and the Marriage Act, Cet. Third, Pt. Pradanya Paramita, Jakarta, 2006, p. 328-329.

29Yahman, Characteristics of Default and Crime Fraud Born of Contractual Relations, Prenadamedia Group, Jakarta, 2014, p. 72.

30 R. Soeroso, Hands Down Agreement in Practical Guidelines Preparation and Application of Law, Sinar Grafika Oppset, Jakarta, 2010, p. 24.

31 PAF Lamintang and Franciscus Theojunior Lamintang, Basics of Criminal Law in Indonesia, Cet. Second, Sinar Grafika, Jakarta, 2016, p. 180. 
offenders. ${ }^{32}$ Departing from that definition, an act can be called a criminal offense, when committed by a person's actions satisfy all the elements outlined in the criminal legislation. The formulation contained in the legislation is an element or condition is a feature or characteristic that can distinguish other acts with criminal acts. In this context, Simons divide criminal elements into elements of subjective and objective elements. The subjective element is the one who is responsible for the emergence of a fault (dolus and culpa). While the objective is the act of those elements, visible legal consequences of such crimes, and the particular circumstances accompanying actions. ${ }^{33}$

In connection with such criminal elements, the lease purchase null and void could also lead to a criminal offense when the withdrawal unilaterally undertaken by businesses. Withdrawal unilaterally undertaken by businesses for reasons of default by the buyer, even though the vehicle financing registered in the Register of Fiduciary result of these actions fall into the category of criminal offense of extortion under Article 368 paragraph (1) of the Criminal Code. Article 368 paragraph (1) of the Criminal Code states that: "Whoever with the intent of enriching himself or another person is against the law to force someone to violence or threats of violence to give a product, which wholly or partially belongs to that person or another person, or in order create or remove a debt receivable, threatened for extortion by a maximum imprisonment of nine months. "The elements of the criminal is a subjective element in the form: whoever; with the intent of enriching himself or another person; unlawfully. While the objective element is forcing people to violence or the threat of violence; that the person or another person give a stuff, which wholly or partially belongs to that person or another person; that the person or another person in order to make debt or delete accounts. that the person or another person give a stuff, which wholly or partially belongs to that person or another person; that the person or another person in order to make debt or delete accounts. that the person or another person give a stuff, which wholly or partially belongs to that person or another person; that the person or another person in order to make debt or delete accounts. ${ }^{34}$

Unilateral withdrawal actions undertaken by businesses in the category of the crime of extortion, because although the financing of vehicles registered in the Register of Fiduciary has executorial force and binding under Article 15 paragraph (1) of Law Number 42 of 1992 on Fiduciary, but the effort of executing the fiduciary objects not necessarily be carried out directly by the entrepreneurs. However, execution on the object fiduciary must also follow the procedures for the implementation of a court decision, so businesses must apply to the Chairman of the Court beforehand, so that it can be implemented in the execution of the object based on title fiduciary executorial contained in the certificate of fiduciary. It refers to Article

32 Ibid, p. 181.

33 Ismu Gunadi and Jonaedi Efendi, Fast and Easy Understanding Criminal Law, Cet. Second, Kencana, Jakarta, 2015, p. 39.

34 Ismu Gunadi and Jonaedi Efendi, Fast and Easy Understanding Criminal Law, op.cit, p. 136. 
224 HIR (Indonesian Herizen Reglement) which states that "Grosse of mortgage deeds and debt securities made before a notary and the head reads" For the sake of justice Based on God "equal magnitude with the judge's decision. If not peacefully, then the letter thus run the command under the leadership of chairman of the court, which is in the jurisdiction where silent or residence of the debtor's or domicile chosen, namely the manner stated in the articles of the past in this section, but with the understanding that force should only be done if the agency had with the judge's decision. If the judge's decision must be executed wholly or partly outside the area of law court that ordered the implementation of the decision, and he must be obeyed the rules of Article 195 paragraph (2) and so on. "Accordingly, Article 196 HIR also states that" if the defeated party is unwilling or fails to meet the decision was well, then the party who won submit an application to the chairman of the district court of the Article 195 paragraph (1), either verbally or by letter, that the decision was undertaken. Then the Chairman will call the losers and rebuked him, that he may fulfill the decision within the time specified by the chairman, forever eight days. "As for when the losing party (debtor) has not been facing, when it had been done calling legally, foreclosure will be run by the clerk of the district court as the provisions contained in Article 197 paragraph (2) HIR. Article 196 HIR also states that "if the defeated party is unwilling or fails to meet the decision was well, then the party who won submit an application to the chairman of the district court referred to in Article 195 paragraph (1), either verbally or by letter, that the decision was undertaken. Then the Chairman will call the losers and rebuked him, that he may fulfill the decision within the time specified by the chairman, forever eight days. "As for when the losing party (debtor) has not been facing, when it had been done calling legally, foreclosure will be run by the clerk of the district court as the provisions contained in Article 197 paragraph (2) HIR. Article $196 \mathrm{HIR}$ also states that "if the defeated party is unwilling or fails to meet the decision was well, then the party who won submit an application to the chairman of the district court referred to in Article 195 paragraph (1), either verbally or by letter, that the decision was undertaken. Then the Chairman will call the losers and rebuked him, that he may fulfill the decision within the time specified by the chairman, forever eight days. "As for when the losing party (debtor) has not been facing, when it had been done calling legally, foreclosure will be run by the clerk of the district court as the provisions contained in Article 197 paragraph (2) HIR. then the side that won submit an application to the chairman of the district court under Article 195 paragraph (1), either verbally or by letter, that the decision was undertaken. Then the Chairman will call the losers and rebuked him, that he may fulfill the decision within the time specified by the chairman, forever eight days. "As for when the losing party (debtor) has not been facing, when it had been done calling legally, foreclosure will be run by the clerk of the district court as the provisions contained in Article 197 paragraph (2) HIR. then the side that won submit an application to the chairman of the district court under Article 195 paragraph (1), either verbally or by letter, that the decision was undertaken. Then the Chairman will call the losers and rebuked him, that he may fulfill 
the decision within the time specified by the chairman, forever eight days. "As for when the losing party (debtor) has not been facing, when it had been done calling legally, foreclosure will be run by the clerk of the district court as the provisions contained in Article 197 paragraph (2) HIR.

Next, when debtors have answered the call of the Chairman of the Court, then the execution on the object fiduciary not necessarily be directly implemented by selling objects on fiduciary, either through public auction or sale under arms as stipulated in Article 29 of Law Number 42 of 1999 on Fiduciary. However, before the sale was made, the debtor will be granted deferral of payment prior to the settlement of the debts arising from the shortage of vehicles and all interest payments due to the occurrence of default.

By contrast, the financing vehicle that is not registered in the Registry Office fiduciary, such agreement in the category of agreements under the hand, so the solution requires a court decision. ${ }^{35} \mathrm{As}$ for when the withdrawal unilaterally carried out by businesses, then this action is included in the crime of extortion as stipulated in Article 368 of the Criminal Code and criminal activities as contrary to Article 3 of the Republic of Indonesia Number Permenkeu 130 / PMK.10 / 2012 concerning the Registration Fiduciary For Consumer Financing Company for Motor Vehicles with Imposition Fiduciary. Article 3 Permenkeu Number 130 / PMK.10 / 2012 concerning the Registration Fiduciary For Consumer Financing Company with the Motor Vehicle Charging of Fiduciary states that "financing companies are prohibited object withdrawal collateral such as a motor vehicle if Fiduciary Registration Office has not issued a fiduciary guarantee certificate and submit it to the Finance Company. "Departing from the rules, then the finance company could be subject to administrative sanctions such as: warning, suspension of business activity, or revocation of business licenses as provided for in Article 5 Permenkeu Number 130 / PMK.10 / 2012 concerning the Registration Fiduciary For Consumer Financing Company for Motor Vehicles with Imposition Fiduciary.

In connection with the efforts to recover the original condition that, when the buyer has returned the object of leasing to businesses, while businesses do not return all the money installments have been received to the buyer, the action does not return the money installments this was exactly what had been included in the crime of embezzlement as under Article 372 of the Criminal Code. Article 372 of the Criminal Code states that "Whoever intentionally and unlawfully possession of something that is wholly or partly belonged to someone else, but it is in his power not because of evil, threatened for embezzlement by a maximum imprisonment of four years or a maximum fine of nine hundred rupiah. "36

35 Muhammad Hilmi Akhsin and Anis Mashdurohatun, Fiduciary Effects Not Signed By-Law Number 42 of 1999, Journal of Deeds, Vol. 4, Number 3, 2017, p. 496.

36 Solahudin, the draft Criminal Law, Criminal Procedure, Civil Code: the Criminal Code, Criminal Procedure Code, KUHPDT, Visimedia, Jakarta, 2008, p. 88. 


\section{CLOSING}

\section{Conclusion}

a. The law of leasing construction does not have legal certainty, as a merger between the act of renting and selling actions certainly have legal consequences vary. However, in case of defaults caused by negligence buyers in doing the payment, then all the money installments initially referred to as the debt will be considered as rent, so that businesses can undertake unilateral withdrawal on the ground that the vehicle rental period has expired.Null and void, because this agreement is not eligible objective form of causa or cause kosher. Non-fulfillment of the terms causa or lawful reason is because there are some clauses that are contrary to the Civil Code and the Consumer Protection Act.

b. Criminal offense arising from the rental agreement to buy a void among other criminal offenses of extortion as stipulated in Article 368 of the Criminal Code withdrawal unilaterally carried out by businesses, although the financing of the vehicle has been registered in the Register of Fiduciary result of these actions fall into the category of acts criminal extortion. The criminal act of extortion arises, because even though the certificate of fiduciary has executorial power as stipulated in Article 15 paragraph 1 of Law Number 42 of 1999 on Fiduciary, while financing vehicles that are not registered with the Registry Office fiduciary will cause this agreement in the category of agreements under the hand, so the solution needs a decision from the court.

\section{Suggestion}

a. Hire purchase agreement that has evolved in the realm of society should not be allowed, because the mixing between acts lease and purchase deeds lead to uncertainty about the legal consequences arising, so that it causes damage to one of the parties, the main buyer.

b. Implementation of credit transactions should not use a motor vehicle hire purchase agreement, but uses a credit purchase and sale agreement with a security object. 


\section{A. Books}

\section{BIBLIOGRAPHY}

Andi Hamzah, offense-offense Specific (Speciale Delicten) Inside the Criminal Code, Cet. Third, Sinar Grafika, Jakarta, in 2017;

Dora Kusumatsusi, Banking Credit Agreement in Perspective, Deepublish, Yogyakarta, 2019;

HR Daeng Naja, Contract Drafting; Skills Series Designing Business Contracts, Citra Aditya Bakti, Bandung, 2006;

I Ketut Oka Setiawan, Legal Engagement, Sinar Grafika, Jakarta, in 2016;

Ismu Gunadi and Jonaedi Efendi, Fast and Easy Understanding Criminal Law, Cet. Second, Kencana, Jakarta, in 2015;

Kartini Muljadi and Gunawan Widjaja, Engagement Born of the Agreement, Cet. Sixth, PT. King Grafindo Persada, Jakarta, in 2014;

Libertus Jaehani, A Practical Guide to Make Agreements and Their Examples, Cet. Second, Visimedia, South Jakarta, 2007;

Marilang, Legal Engagement, Engagement Born of the Agreement, Indonesia Prime, Napier, 2017;

Munir Fuady, Business Law in Theory and Practice Book Three, Cet. Third, Pt. Citra Aditya Bakti, Bandung, 2017;

Oemar Mochtar, Fundamentals of Engineering Manufacture Deed, Airlangga University, Surabaya, 2017;

PAF Lamintang and Franciscus Theojunior Lamintang, Basics of Criminal Law in Indonesia, Cet. Second, Sinar Grafika, Jakarta, in 2016;

R. Subekti, Assorted Testament, Pt. Citra Aditya Bakti, Cet. All 10, Bandung, 1995;

R. Soeroso, Hands Down Agreement in Practical Guidelines Preparation and Application of Law, Sinar Grafika Oppset, Jakarta, 2010;

Artha Windari Ratna, the Law of Treaties, Graha Science, Yogyakarta, 2014;

Salim HS, innominate Contract Law Developments in Indonesia, Cet. Fourth, Sinar Grafika, 2008;

Contract Law Theory \& Mechanical Drafting Contracts, Cet. 11, Sinar Grafika, Jakarta, in 2015;

Samuel Mp. Hutabarat, Offer and Acceptance in the Contract Law, Grasindo, Jakarta;

Soerjono Soekanto and Sri Mamudji, Normative Legal Research (A Brief Overview), Eagle Press, Jakarta, 2001; 
Solahudin, the draft Criminal Law, Criminal Procedure, Civil Code: the Criminal Code, Criminal Procedure Code, KUHPDT, Visimedia, Jakarta, 2008;

Suharnoko, Contract Law Theory and Legal Analysis, Cet. Ninth, Kencana, Jakarta, in 2015;

Suteki and Galang Taufani, Legal Research Methodology (Philosophy Theory and Practice), Eagle Press, Jakarta, in 2018;

Yahman, Characteristics of Default and Crime Fraud Born of Contractual Relations, Prenadamedia Group, Jakarta, in 2014;

\section{B. Journals}

Jeinal Bawarodi, Hire Purchase Agreements Implementation in Indonesia and Effect Law, Lex Privatum, Vol. II, Number 3, 2014;

Muhammad Hilmi Akhsin and Anis Mashdurohatun, Fiduciary Effects Not Signed ByLaw Number 42 of 1999, Journal of Deeds, Vol. 4, Number 3, 2017;

Vienna P. Setiabuddi, Default Vehicle Hire Purchase Agreement, Unsrat Law Journal, Vol. 1, Number 1, 2013; 